\title{
FAKTORANALÍZIS, A LÁTSZATMEGOLDÁS ${ }^{1}$
}

\author{
(Factor Analysis: a Pseudo-Solution)
}

\section{CZIRFUSZ MÁRTON}

Kulcsszavak:

faktoranalizis összetett fogalmak mérése absztrakció térfetisizmus területi szintek

A területi elemzések a faktoranalizisre, mint az összetett fogalmak mérését megoldó eljárásra tekintenek. A tanulmány a módszer "mögött" levö elméleti problémákat elemez, megkérdójelezi a faktoranalizis altal kinált megoldás univerzalitását. A cikk feltár néhány, a faktoranalizis absztrakciós lépéseiben megbúvó ellentmondást, valamint vizsgálja a térbeliség és a terïleti szintek szerepét az eljárás lefolytatásában.

\section{Bevezetés}

A területi elemzési módszerek lehetőségként való használata mellett - számos tanulmányban a módszerek hasznossága doxává (Bourdieu 2002) vált - kevés írás foglalkozik a módszerek korlátainak elemzésével. Az eljárások adta lehetőségek rossz színvonalú kihasználása inkább a módszerhasználat hiányosságaira vezethetỏ vissza (Nemes Nagy 1988), ezzel szemben a korlátok elemzése összetettebb, hiszen a háttérben meghúzódó elméleti, filozófiai megfontolások számbavételét is szuikségessé teszi. Foucault (2001) terminológiájával élve utóbbi elemzéseknek az elsődleges viszonyok (a valós világon, a vizsgált tárgyon belüli kapcsolatok) rendszere felöl a másodlagos és harmadlagos viszonyok (gyakorlatok, diskurzusok) rendszere felé szükséges elmozdulniuk. A módszereket így nem önmagukban, hanem elméletekkel és kutatói gyakorlatokkal együttesen szükséges elemezni (Aitken-Valentine 2006).

Tanulmányunkban a faktoranalízist ebből a nézőpontból vizsgáljuk, a szakirodalomban jobbára mellözött, a módszer „mögött”" levő, legtöbbször nem kifejtett elméleti megfontolásokra koncentrálva. Vagyis a faktoranalízis kritikájával foglalkozunk, rést kívánunk nyitni a faktoranalízis fekete dobozán (Latour 1999). Ennek következtében írásunk szükségszerúen destruktív (Belina 2008). Nem mondja meg, hogy „,mit kell tenni” (Foucault 2007); pusztán problematikus pontokra mutat rá a módszer gondolatiságában és használatában.

A tanulmányban érintett kérdésköröket két részre bontottuk. Egyikük a módszer alkalmazása során a kutatók által hozott absztrakciós döntésekre és az absztrakciós folyamatra összpontosít. A másik a faktoranalízis és a területi kutatások viszonyával foglalkozik, a földrajz és a regionális tudomány számára is létkérdésnek számító tér és hely szerepén keresztuil. Állításainkhoz példákat az elmúlt években publikált hazai terìleti kutatásokból társítottunk. Ezek közül részletezettsége folytán kiemelten kezeltük a (második) klasszikus magyarországi falutípus-vizsgálatot (Beluszky-Sikos T. 2007), de a vitatott pontok valamennyi hasonló területi vizsgálatra is vonatkoztathatók. 


\section{Absztrakció}

A faktoranalízis absztrakción alapul. A körülöttünk levő világot bizonyos elöre meghatározott szempontok (szabályok, törvények) mentén leegyszerủsíti, interpretálja. Paul Feyerabend rámutat, hogy az absztrakción alapuló módszerek eredményei nem a valóságot adják vissza. Amennyiben valaki ennek ellenkezójét állítja, az a vallásból (hitből) ered, így nincs köze magához az absztrakcióhoz. Ugyanakkor Feyerabend nem kérdőjelezi meg, hogy az absztrakció révén új információkhoz jutunk és új technikákat hozunk létre (Feyerabend 1998). Ezeket a kutatói konstrukciókat viszont általában a valóság (egyetlen) helyes leképezésének tartják (Boudon 2006), sem a kutató, sem kutatótársai nem dekonstruálják.

A faktoranalízis során megvalósuló absztrakciós folyamat három csomópontját emeljük ki a továbbiakban. Először a módszer használatának elején szerepet játszó dimenziók és változók, valamint az eredményként kapott, a változókkal kapcsolatban álló faktorok problematikáját elemezzük. A második gondolatsor a faktoranalízis magjához, a korrelációszámításhoz vezet. Végül a módszer által feltárható világban honoló rend feltételezésének és keresésének következményeivel foglalkozunk.

A faktoranalízis módszerének alkalmazásában megfigyelhető egy de- és rekonstrukciós láncolat. Általában dimenziók meghatározásával konceptualizáljuk a vizsgálandó jelenséget, majd azokat mennyiségi változókkal képezzüik le. A változók összevonásával a faktoranalízis eredményeként faktorokat, ismét dimenziókat kapunk (SzékelyiBarna 2002). A kezdeti és a végső dimenziók ugyanakkor eltérő tulajdonságokkal bírnak: a kezdetiek között összefüggések vannak (Nemes Nagy 2009), ezzel szemben a faktorok egymástól - legalábbis látszólag - függetlenek.

Székelyi és Barna (2002) rámutatnak, hogy a faktoranalízis használatakor a háttérben látens, mérhetỏ változókkal leképezhető dimenziók munkálását kell feltételeznünk. A rejtett dimenziók feltételezése a területi vizsgálatokban gyakran elsikkad. Pedig a gondolat nem kellene, hogy újdonságként hasson. A látens dimenziók és a régiók objektív létének feltételezése ugyanazon ismeretelméleti álláspontot hordozza, ahol logikus vizsgálati célként merül fel ezen objektív létezók (a dimenziók, illetve a régiók) feltárása. Míg az utóbbi gondolatot (a régiókat csak fel kell fedezni - Tóth 2004) a szakmai közvélemény egy része gyanakvással kezeli (Enyedi 2005), addig az elỏbbi megkérdőjelezése teljesen hiányzik. Holott a megfogalmazások helyenként ellentmondóak. Nemes Nagy említi, hogy a fejlettségi vizsgálatokban a faktoranalízis eredményeként gyakran „,megjelenik egy-egy urbanizáltsági dimenzió, faktor, anélkül, hogy az eredeti adatbázisban a városi fejlettséget tükrözó adatok elkülönült csoportja megjelent volna" (Nemes Nagy 2009, 310). Az urbanizáltsági dimenzió nem objektív létező, amelyet a faktoranalízis (illetve az azt végző elemző) felfedezett, hanem a megnevezés aktusával létrejött kutatói konstrukció.

A látens dimenziók tényként kezelésének hátterében egy nem megalapozott általánosítási folyamat, módszerhasználati felületesség állhat. Nemes Nagy rámutat, hogy a területi kutatásokban a fejlettség és hasonló sokdimenziós fogalmak mérésének igénye 
vezetett a faktoranalízis elterjedéséhez (Nemes Nagy 2009). Ezzel szemben több vizsgálatban is meglehetôsen ködös marad, hogy milyen jelenséget vizsgálnak faktoranalízissel, és az valóban sokdimenziós-e. Egyszerủen megelégednek azzal, hogy a módszerrel „olyan új, komplex (latens) változók számíthatók, amelyek kapcsolatban vannak a kiinduló adatokkal" (Nemes Nagy 2009, 306).

Ebből a szempontból Beluszky és Sikos T. elemzése is ellentmondásos. Könyvük bevezetőjében hangsúlyozzák, hogy a faluformáló folyamatokat kívánják feltárni, a faktoranalízist bevezető gondolatokban viszont az életkörïlmények mérhetővé tételéröl írnak (Beluszky-Sikos T. 2007). Nyilvánvalóan a két dolog között átfedések vannak, viszont semmiképpen sem ragadhatók meg ugyanazokkal a dimenziókkal. Hasonlóan problematikus Adler és munkatársai vizsgálata (Adler et al. 2001). Tanulmányuk címében a gazdasági fejlettség szerepel (természetesen ez is egy sokdimenziósnak elfogadható jelenség), a bevezetö célkitüzése alapján viszont az elemzés a gazdaság térbeli szerkezetét kívánja bemutatni. A hiba jól szemléltethető a területi adatmátrixon: az egyik megközelítés a területi adatmátrix soraival, a másik annak oszlopaival dolgozik, a két közelítés nem összemosható (Czirfusz 2007).

A végeredményként kapott faktorok esetében az interpretációs nehézségeket egy nem feloldható kettősség adja. A faktorok azt sugallják, hogy a valóság egymástól független részekre osztható fel (hiszen a faktorok egymással korrelálatlanok), ugyanakkor a faktorok a változókon keresztül mégis kapcsolatban állnak egymással (vagyis a valóság egy-egy szelete közös). A korrelálatlanság ténye mindenképpen írástechnikai előny, az egyes faktorok egymás után, egymástól függetlenül tárgyalhatók anélkuil, hogy a módszer logikájának ellentmondanánk. Amíg csak $\mathrm{F}_{1}, \mathrm{~F}_{2}$ stb. faktorokról beszélünk (Beluszky-Sikos T. 2007), valójában nincs gond: léteznek absztrakt faktorok, amelyek a modellezett valóság egymástól független vetületeit képezik le (Fassman[n] 1991). Ez a megállapítás viszont a folyamatok megértéséhez nem nagyon visz közelebb. A megnevezés mozzanata az, amelynek révén a faktorok által kifeszített tér megismerhetö, racionalizálható, ám a problémák is itt lépnek fel.

$\mathrm{Az}$ első probléma a faktorok korrelálatlanságára vezethetô vissza. Beluszky és Sikos T. harmadik faktora a demográfiai helyzet elnevezést kapta, negyedik faktora pedig a népességszám-változás dinamikáját ragadja meg (Beluszky-Sikos T. 2007). Mivel a faktorok korrelálatlanok, a demográfiai helyzet szükségszerüen függetlennek minősül a népességszám-változástól és fordítva is. Ez a kijelentés viszont hétköznapi tapasztalatainknak ellentmond. Nem biztos, hogy segíti a valóság megértését, épphogy elbizonytalanító hatású.

Másodsorban a faktorok elnevezését érdemes összehasonlítani a kezdeti dimenziók elnevezésével. Ha ugyanis ez utóbbiakat a faktorokkal visszakapjuk (és a modell magyarázó ereje magas), a hipotézis megfelelö volt, de a számítások hozzáadott értéke elhanyagolható. Egyéb esetekben viszont logikai ellentmondás tapasztalható. Adler és munkatársai a vizsgálat elején gazdasági, jóléti, infrastrukturális, demográfiai és közigazgatási „részfejlettségeket” (dimenziókat) különítettek el, eredményként pedig gazdasági, jóléti és demográfiai faktorokat kaptak. Ezzel azt is sugallták, hogy az infrastrukturális és közigazgatási dimenziókat leképező változók „estek ki” 
a faktoranalízis alkalmazásakor, azok alkotják a modell nem magyarázott részét. Viszont, ha ez a helyzet, akkor a módszer logikájában gondolkodva a kezdeti feltételezés (öt dimenzió) hibás volt, azaz az infrastrukturális és közigazgatási helyzet nem önálló magyarázója a vizsgált jelenségnek, a fejlettségnek. Továbbá hangsúlyozták, hogy a települési jogállástól és mérettől független fejlettséget kívántak leírni, ám az elemzésben számtalan helyen kiemelték, hogy a településméret számít, vagyis dimenzióként szükséges lett volna figyelembe venni (Adler et al. 2001). Szélsőséges esetben a módszer helytelen használata önigazoló jelleget ölthet: a kutató addig alakítja a kezdeti változó- és dimenzióhalmazt, amíg a faktorokkal viszszakapja a feltételezett dimenziókat, ezzel magas magyarázó erőt elérve.

A faktorok létrejöttiikkkel, megtalálásukkal - a kutató aktív közremüködésével néha önálló életre is kelnek, cselekvővé válnak. Az absztrakció nem vállalható szintjét jelenti az az állítás, hogy a „változók közötti korrelációs kapcsolatokat több faktor hatása idézi elo" (Beluszky-Sikos T. 2007, 118), a világban ugyanis a jelenségek anélkül is hatnak egymásra, hogy azt bárki is faktoranalízissel megvizsgálta volna. Ráadásul a módszer nem feltételez ilyen hatásokat a faktoroktól, hiszen a faktorok „alakulnak ki” a változókból. Sem a módszerek, sem azok eredményei nem önálló cselekvởk (azaz, szemben a szerzők állításával, nem a klaszteranalízis osztályozza a falvakat [Beluszky-Sikos T. 2007]). Mindezek absztrakt dolgok, amelyeket a kutatók azért hoznak létre, hogy a körülöttük levő világot jobban megértsék.

A faktoranalízis deduktív tudományos módszer. Kiinduló feltételeket határoz meg jórészt ezekhez kapcsolható problémákról szól ez a tanulmány -, majd egy elöre meghatározott eljárásrendet alkalmazva leírja az empirikusan tapasztalt jelenségeket. A törvények a dedukció logikájából adódóan kikerülhetetlenek (Barnes 2004). A faktoranalízis esetében a háttérben meghúzódó „törvények” a korrelációszámítás (SzékelyiBarna 2002) és a regresszióanalízis, vagyis az, hogy két jelenség között kapcsolatot feltételezve a köztïk levő kapcsolat leírható egy regressziós egyenessel. A kétváltozós korreláció- és regressziószámításnál a változók módszerhasználat révén konstruált kapcsolatai (át)láthatóbbak: előre tudjuk, hogy milyen változók között számolunk. A faktoranalízis esetében nem; de éppen ez az eljárás „értelme”: a változók, jelenségek közötti „rejtett” kapcsolatok vagy együttmozgások feltárása. Viszont az együttmozgás nem feltétlenül jelent ok-okozati kapcsolatokat. Nyilvánvalóan kevéssé járul hozzá a körülöttünk levő világ megértéséhez, ha olyan pontokon feltételezünk oksági kapcsolatokat, ahol általános tapasztalataink (egyedi tapasztalataink összessége) szerint inkább véletlen együttmozgás feltételezhető (lásd még Kitchin 2006).

Talán a problémát itt is a számszerüsített eredmények verbalizálása okozza. A verbális leírás matematikai formalizálása segíti a megértést (Dusek 2004), ám fordítva, a matematizált tartalom szavakba öntése az interpretációs lehetőségek miatt sokszor veszélyeket rejt.

A kapott faktorok és a kezdeti dimenziók közötti kapcsolatok interpretálása során Beluszky Pál és Sikos T. Tamás beleesett abba a csapdába, amelyet az alapadatok és alapdimenziók „alattomosan” felkínálnak. Miután felsorolták a faktoranalízis során használt 27 változót, erősíti a választás legitimációját, ha a változókat részle- 
tesen is bemutatják; ez a mintegy ötvenoldalas $A$ falvak helyzete a vizsgálatba bevont mutatók alapján címü rész. A probléma abban áll (és ez nem a módszer korlátja!), hogy itt megelőlegezik a faktoranalízis eredményeit, egy verbális (számok nélküli) faktoranalízist hajtanak végre, ahol az alapváltozók eloszlásgörbéi és a települési adatok térképezése mellett a változók közötti kapcsolatok (a hatótényezők) intuitív és a szerzők szakmai felkészültségén alapuló bemutatása is hangsúlyos. Söt, ezek dimenziókba („faktorokba”) való összevonása is megtörténik (pl. aprófalutünetcsoport). A logikai bukfenc nyilvánvaló: ha a változókon keresztül bemutathatók a településformáló folyamatok és azok összefüggései, akkor közel teljes képpel rendelkezünk a valóságról, nem léteznek a kutató számára rejtett dimenziók, vagyis a faktoranalízis elvégzése teljesen szükségtelen. A könyvben viszont ellentmondásokkal terheltté válik a vizsgálat: a termőföldek értékszáma a „verbális faktoranalízis" alapján összefüggésben van a települések méreteivel, ezt az alapmutatók korrelációs mátrixa nem erősíti meg (a két mutató között 0,2 alatti a korrelációs együttható értéke), sőt, az agráradottságok önálló faktorként jelentek meg (amelyben kizárólag a termőföldek értékszáma szerepel, a települések népességszáma nem) (Beluszky-Sikos T. 2007). Az ilyen és hasonló jellegü ellentmondásokra sajnos a szerzők nem voltak tekintettel, így nem tettek kísérletet feloldásukra sem.

További, a módszer lehetőségeiből adódóan nem egyértelmủen eldönthetỏ kérdés, hogy a faktoranalízis használatakor a mutatókon (változókon) vagy a köztük levő relációkon van a hangsúly. A módszer mechanizmusai alapján a kapcsolatok az elsődleges mozgatók, az eljárás technikailag nem változik meg, ha más mutatókkal végezzük el. Másrészről viszont a konkrét elemzésekben a mutatók az elsődleges fontosságúak (fỏleg, ha a változók számának csökkentése a cél), bár kiválogatásuk a módszertől független konceptualizálás és operacionalizálás része. A két eltérỏ megközelítés (amely jól kapcsolható az abszolutista és relativista térfelfogás megkülönböztetéséhez) eltérő interpretációt eredményez. A mutatók középpontba helyezése vezet a megfigyelési egységek faktorértékeinek megszövegezéséhez. Ez az irány szükségszerüen leíró jellegủ; a faktorértékek térképezhetők, de a módszer alkalmazásával nem magyarázhatók és nem magyarázandók. A magyarázandók az eljárással feltárható kapcsolatokra hangsúlyt helyezve, így a faktorértékektöl eltekintve azok a mechanizmusok, amelyek a kapcsolatokat létrehozták. A két irány véleményünk szerint kiegészíti egymást, teljesen eltérő kérdésekre keres választ, aminek tudatosítása minden vizsgálat szempontjából szükségszerü.

A faktoranalízis segítségével jelenségek közötti kapcsolatok, valamiféle rejtett rend tárható fel. A rend (a törvények) keresése erősen jelen van a társadalomföldrajz tértudományi irányzatában és a regionális tudományban, a faktoranalízis használatában ugyanakkor mindenképp ellentmondásos a szerepe.

A rend és a rendezetlenség viszonya megbillen annak következtében, hogy a módszer társadalmi tartalmat vizsgál. Gregory (Foucault nyomán) utal rá, hogy a természettudományok történetében a törvényeket, az „objektív tudományokat” megfigyelésekböl (mérésekböl, számszerüsítésekböl) vezették le (Gregory 1994). A területi kutatások kvantitatív módszereinél ugyanez a helyzet: „Mérj, hogy követ- 
kezhess!" (Nemes Nagy 1988, 70). Ezen nézetek a természettudományos gondolkodásmódba helyezik a kvantitatív területi kutatásokat, ahol a „kísérletek” megismételhetők és megismételendők ahhoz, hogy általános törvényszerüségeket állapíthassunk meg. Ugyanakkor a cikkírási gyakorlat inkább ellentmond ezeknek a követelményeknek. A legtöbb tanulmány alapján nem lehetne reprodukálni a faktoranalíziseket, hiányzik a vizsgált változók bemutatása, az eljárások pontos ismertetése, a keretfeltételek - például a dimenziók meghatározásának - leírása. Az egyébként nagy részletességgel bemutatott magyarországi falutípus-vizsgálat azon megállapítása, hogy „egyes konkrét vizsgálatok mások által nem ismételhetök meg” (Beluszky-Sikos T. 2007, 116) így teljesen indokolatlanul megkérdőjelezi bármely faktoranalízis tudományos voltát.

A természettudományokban (és több esetben a társadalomtudományokban) a rend keresése a tudományok elsődleges célja. A rend keresésének és megtalálásának négy módja közül - teológiai mód, esztétikai és érzelmi út, a józan ész használata, valamint tudományos eljárások - nyilvánvalóan ez utóbbi bizonyult a legfontosabbnak (Johnston-Sidaway 2004). A faktoranalízis szempontjából a problematika abban ragadható meg, hogy "teljesen" tudományosan az eljárás nem hajtható végre, a vizsgálat ,,minden objektivitása ellenére szubjektív elemeket tartalmazó döntéseket is igényel" (Beluszky-Sikos T. 2007, 116), elsősorban a dimenziók és változók már említett kiválasztása kapcsán.

A rend keresésének másik, ám az előzőekkel összefüggő vonulata érthető meg Doreen Massey gondolatmenetéből. A szerzo a „kvantitatív korszak” korrelációszámításaira visszautalva teszi fel a költöi kérdést, hogy , mi lehet determinisztikusabb a magas $R^{2}$ keresésénél?" (Massey 1995, 15) A faktoranalízis kapcsán is van a kérdésnek létjogosultsága: a „legjobb” változat keresése a magas magyarázó erőhöz való ragaszkodás révén sajátságos determinizmus által sújtott. A módszertani útmutatókban (Székelyi-Barna 2002; Nemes Nagy 2005) jól érzékelhetők ezen, kifejezetten módszerhasználati hibára csábító iránymutatások: a magyarázó modell jóságát pusztán különböző kimeneti számértékek (sajátértékek, kumulált $\mathrm{R}^{2}$, korrelációs együtthatók stb.) alapján ítéljük meg, kimerítve a latouri feketedoboz-effektus (Fassman[n] 1991; Latour 1999; Barnes 2001) ismérveit. Feyerabend nyomán egy olyan absztrakciós folyamatról beszélhetünk ebben az esetben, amelynél eltekintünk bizonyos dolgoktól, a maradékhoz hozzáteszünk bizonyos konstrukciókat, így számokat $\left(R^{2}\right)$ kapunk. A számok esetenként hasznosak lehetnek, de nem hihetjük, hogy ilyen módon az objektív valósághoz jutottunk el (Feyerabend 1998).

Elöbbi gondolatokban a racionális rend keresése és az esztétikum összeér. A faktoranalízis nemcsak az objektív, hanem a szép és elegáns valóságot hivatott leképezni. Az átlagostól (a törvényszerütől, a regressziós egyenesek által meghatározott determinisztikustól) eltérö információk a faktorok kialakítása során elvesztendők, értéktelenek. A faktoranalízis célja a „szép faktorstruktúrák” létrehozása (Székelyi-Barna 2002, 108). Az alacsony magyarázó erejú változókat ki kell vennünk a vizsgálatból (Nemes Nagy 2005). Az a harmonikus, ha a faktorértékek valamennyi megfigyelési egységben egyaránt jók (Adler et al. 2001). Ez az esztétikai 
vonulat a tértudományi irányzatnak általában is nem titkolt sajátja: Haggett szerint a szimmetria és az elegancia nagyon gyakran kéz a kézben jár az igazsággal (idézi Gregory 1994), a mennyiségi elemzéseknek kultúrája van (Nemes Nagy 1988).

\section{A földrajz halála?}

A faktoranalízis általánosan használt társadalomtudományi módszer, amelyet a területi kutatások is felfedeztek maguknak. Ugyanakkor az eddigi vizsgálatok nem fordítottak túlságosan nagy figyelmet a módszer területi vizsgálatokat illető jellemzőire, következményeire. A továbbiakban azt a problematikát elemezzük, amely a területi tartalom, illetve a megfigyelési egységek lokalizálása körül fellép.

Immanuel Kant szerint az osztályozások logikai és fizikai alapon történhetnek. Első esetben a dolgokat hasonlóság alapján helyezzük egy csoportba (tulajdonképp ez történik egy faktor- vagy egy klaszteranalízis során), utóbbinál (ide sorolta Kant a földrajz- és a történettudományt) a közelség az egy osztályba sorolási ismérv (Gregory 1994). A két eljárás különbözik, a faktoranalízis esetében első közelítésben a földrajzi tartalom teljes halálát jelentve. A továbbiakban arra a kérdésre keressük a választ, hogy vajon a földrajzi tér megjelenik-e valamilyen módon a faktoranalízis alkalmazásakor, vagy a tér és a hely pusztán adatgyüjtési entitásként van jelen?

A módszer első́dlegesen kevéssé tekinthetö tér- vagy regionális tudományinak, hiszen a (külsö) térbeliségnek nincs kitüntetett szerepe az eljárás során (Nemes Nagy 2009). A térbeliség-területiség a területileg csoportosított adatokon keresztül jelenik meg: azok magukat a megfigyelési egységeket jellemzik (Dusek 2004), illetve a módszer segítségével területegységekre vonatkozóan fogalmazhatunk meg állításokat. Azonban az eljárás lefolytatásában teljesen mindegy, hogy megfigyelési egységeink például települések vagy kistérségek, illetve hogy hol helyezkednek el. Ez a tény viszont egyaránt vezet térfetisiszta és térnihilista-totalizáló álláspontokhoz, ami belső ellentmondásokat hordoz a módszer használatában.

Hagyományos értelemben térfetisisztának nevezzük azokat a megközelítéseket, amelyek önálló (és sokszor kizárólagos) magyarázó erőt tulajdonítanak a térbeli elhelyezkedésnek. Ezen vélemények szerint így létezik a térbeli jelenségek tudománya, sớt, a térbeli szabályszerủségek térbeli tényezőknek köszönhetők (Massey 1985). A faktoranalízistöl alapesetben igen távol állnak ezek az elképzelések, hacsak nem térbeli elhelyezkedést leíró változókból indulunk ki. Az eredmények interpretálásában-magyarázatában viszont a térfetisizmus visszalopakodik, Nemes Nagy például az egyes társadalmi-gazdasági dimenziók térszerkezetének kölcsönös függöségéröl ír (Nemes Nagy 2009). Pedig a faktoranalízis alkalmazásával csak a társadalmi és gazdasági tartalomról (a dimenziók és változóik kapcsolatairól) tudunk megállapításokat tenni, a térbeliről (a területegységek kapcsolatairól, a térszerkezetről) egyáltalán nem. A módszer regionalisták számára szomorú valósága, hogy általános megközelítésmódjukkal szemben (ahol a térbeliségnek vezetö, de legalábbis hangsúlyos magyarázó ereje van [Massey 1985]) a társadalmi (gazdasági) 
tartalom válik elsődlegessé, a térbeliség alárendelt. A térbeliség magyarázó erejét az eljárás lefolytatása után a faktorértékek térképezése lenne hivatott bemutatni.

A faktorértékek térképezése, csakúgy mint a tértudományi irányzat valamennyi térképező projektje esetében, az objektívnek tartott valóság megjelenítését szolgálja. Descartes és Kant számára az ilyen eljárások a saját tudás (,az igazság szigetei”) legitimálását és minden ezen túli ismeret elértéktelenítését (,az illúzió óceánja”) egyaránt jelentik (Gregory 1994). Nyilvánvalóan a faktoranalízis tudomást vesz a többi ismeretről (erre példa Beluszky és Sikos T. már említett „verbális faktoranalízise"), ugyanakkor Gregory látványosan mutat rá a hiányosságokra.

Éppen amiatt, hogy a módszer maga nem használ területi, csak térségi adatokat (Dusek 2004), a térképezés interpretálása nem könnyü. A faktorértékek térképeinek „elemzése" nem mutathat túl a térképek egyszerü megszövegezésén (hol magasabbak és hol alacsonyabbak az értékek). A leírások során így a határok meghúzogatása és a regionalizálás (alacsonyabb és magasabb értékekkel rendelkező térségek elhatárolása) dominál, ez utóbbi viszont problémákat jelent a területi szinteket illetően (lásd később). Ha viszont az elemzések a leírásnál többre vállalkoznak, szüksségszerüen eltávolodnak magától a faktoranalízistől, ellentmondásba is kerülhetnek vele. A gondot az okozza, hogy a faktoranalízissel a sokaság egészére tudunk kapcsolatokra vonatkozó állításokat megfogalmazni, egyes megfigyelési egységek közötti különbségek ebből a szempontból nem létezhetnek. Így szembekerül egymással a módszer térnihilista, generálisat állító (azaz determinista [Sayer 1985]) és a térképezés különbségeken alapuló (ha a tér homogén lenne, nem kellene térképezni) térfetisiszta álláspontja.

A faktoranalízis módszerével a kutató maga is tereket teremt. Bottlik Zsolt például faktortereit Descartes-féle koordinátarendszerben ábrázolja. Amint viszont a gazdasági helyzet kétdimenziós faktorterébe egy újabb, az eredeti mutatóktól addig függetlenként kezelt változó (a nemzeti kisebbségek száma) tapasztalati értékek alapján megrajzolt izovonalait is feltünteti (Bottlik 2008), a vizsgálat problematikussá válik. Ugyanis ezzel a szerző szükségképpen azt is állítja, hogy minden faktorértékpárhoz egyértelmủen hozzárendelhetünk egy nemzeti kisebbségi létszámot. Az ok-okozati viszonyok pedig csak ebben az irányban lehetnek érvényesek, hiszen adott kisebbségi számhoz az ábra alapján végtelen számú, de más-más faktorértékkombinációjú pont tartozik a faktortérben, tehát a kisebbségek számából nem következtethetünk egyértelmủen a térségek gazdasági helyzetére.

A térfetisiszta állásponttal szemben - a földrajz idiografikus és nomotetikus jellegéről szóló vitához (lásd többek között Probáld 1995) visszakanyarodva - a helyek egyediségét hangsúlyozó álláspontok helyezkednek el, amelyek az 1970-es évektöl a hangsúlyt a társadalmi folyamatok által létrehozott térbeli jelenségekre helyezték. Ezzel ugyan az okok vizsgálata közvetlenül kikerült a földrajz vizsgálati terrénumából (hiszen az irányzat képviselői szerint nem a térbeli, hanem a társadalmi okok a mozgatórugók), de a gondolat egy nagyon erős lokalizálási mozzanattal (adott helyeken konstruált tudás) is együtt járt (Massey 1985; Barnes 2001; 2004). A faktoranalízises vizsgálatok során viszont a két álláspont keveredik, ismét logikai ellentmondásokat okozva. Amint már az előbbiekben kifejtettük, a faktoranalízis a 
sokaság egészére fogalmazza meg a relációkat, azaz ebböl a szempontból térnihilista; feltételezi, hogy a változókészlet univerzális, valamint, hogy a jelenségek (változók) közötti kölcsönkapcsolatok minden egyes megfigyelt helyen ugyanúgy érvényesülnek. Ennek fényében különösen izgalmas Nemes Nagy eszmefuttatása a (faktoranalízissel végzett) fejlettségvizsgálatok tanulságai kapcsán. Ha nem létezik tértől és időtől független dimenzió- és mutatószám-rendszer a fejlettség mérésére, akkor nem lehet ugyanazzal a mutatórendszerrel több időpontra és eltérổ megfigyelési egységekre bontott entitásokra faktoranalíziseket készíteni (Nemes Nagy 2009). Ezen túl viszont az állítás (és erről Nemes Nagy már nem ír) szuikségszerủen megsemmisítöleg hat valamennyi faktoranalízisre, hiszen így az alapfeltételezés, miszerint a kölcsönkapcsolatok valamennyi megfigyelési egységnél ugyanazok, sem elfogadható. Ezen a tényen Nemes Nagy egyértelmúen átsiklik. Tény, hogy állításunkkal ugrottunk egy területi szintet (azaz a magasabb szinten érvényes állítást kiterjesztettük az alacsonyabb szintre), de ez nem befolyásolja annak érvényességét.

A területi szintek problematikája - az előbbieket továbbgondolva - a faktoranalízis során abban áll, hogy az elemzések nem mindig veszik figyelembe, hogy a vizsgált jelenség térségi szinttől függgően teljesen eltérỏ tartalmú lehet. Ennek az elöbbiekkel összhangban két vonulatát elemezzük részletesen: a területi szintek szerepét az alapváltozók kiválasztásában, valamint a változók közötti kapcsolatok interpretálásában.

A faktoranalízis absztrakciós folyamatának elején a vizsgált kérdéskört mutatókkal szükséges leképezni. Az adatok kiválogatásában természetesen azok rendelkezésre állása fontos szempontként merül fel. Ugyan „tisztázni kell, hogy az elméleti alapkérdések milyen térbeli aggregátumszinten érvényesek" (Fassman[n] 1991, 75), de a kérdésre a legtöbb vizsgálat nem fordít kellő figyelmet. Ez pedig a területi szintek összemosását eredményezi a faktoranalízisekben.

A módszerhasználati hiba több munkában egyértelmủen látszik. Adler és munkatársainak vizsgálata célként tűzte ki, hogy bemutassa a gazdaság térbeli szerkezetét, amelyet, mint az előzőekben utaltunk rá, ők hibásan a megyék-régiók fejlettségével és elmaradottságával azonosítottak (Adler et al. 2001). Ha viszont a megyék vagy a régiók fejlettségi különbségeinek feltárása a feladat, akkor ilyen területi szintủ adatokkal kell dolgozni, és nem településiekkel, mint ahogy a szerzők tették. Ennek oka egyrészt, hogy teljesen eltérő mechanizmusok teljesen különbözően mủködhetnek különbözö szinteken, másrészt még ha elfogadható absztrakciónak is tekinthetö, hogy a kapcsolatok ugyanazok, a módosítható területi egység problémájának skálázási hatása mindenképpen fellép (Dusek 2004). Így hibás Bíró és Molnár (2004) kistérségi fejlettségvizsgálata is, amely minden kommentár nélkül az előbbi települési-megyei elemzés dimenzióiból indul ki.

A területi szintek közötti ugrás (jumping scales), a jelenségek-mechanizmusok átskálázása (Füller-Michel 2008) később a másik irányban is megvalósul. A települési faktorértékeket Adler és munkatársai valamilyen nem részletezett eljárással aggregálták megyei szintre, valamint településtípusok (településméret) szerinti csoportokra (Adler et al. 2001). Faluvégi Albert még durvább módszertani hibát követ el a kistérségi faktorpontértékek népességszámmal súlyozott regionális szintủ átlagolásával 
(Faluvégi 2005). A szöveges interpretációk nagy részét ezen adatok elemzése (az egyes csoportosított faktorértékek sorrendbe helyezése és összehasonlítása) teszi ki. Még egyszer hangsúlyozzuk, hogy minden egyes, területileg eltérően csoportosított adatmátrixra külön lett volna szükséges a faktoranalízis módszerét alkalmazni, a vizsgálat csak így lett volna érvényes.

Hasonló módon problematikusak azok az eredmény-megszövegezések, amelyekben az esetlegesen térképezett faktorértékek verbálisan kerülnek aggregálásra. Egy települési adatokból kiinduló elemzésben csak óvatosan mondhatjuk például, hogy Györ-Moson-Sopron megyében az első faktor értékei magasak, hiszen a faktorok csak a települési szinten jönnek létre a módszer alkalmazásakor, a megyei szinten valójában nem ,léteznek”.

A változók közötti, faktoranalízis során feltárt kapcsolatoknál szintén fontos az érvényesség kritériumának megfelelő területi szint megtalálása. Minden vizsgálatnál indokolandó, hogy milyen módon járhatók át a területi szintek a relációk interpretálása során. A probléma ismét az absztrakció és a köznapi valóság ütközése miatt lép fel. Induljunk ki települési adatokból, és tételezzük fel, hogy az egy fôre jutó jövedelem és a személygépkocsi-ellátottság mutatói között magas korrelációs együtthatót kaptunk. A korrelációs kapcsolatok interpretálásakor csak a településekre vonatkozóan fogalmazhatunk meg állításokat és nem az egyénekre vonatkozóan (Dusek 2004; Werlen 2008). A vizsgálattól és annak absztrakciójától eltekintve azt mondanánk, hogy a kapcsolatok egyéni (egyedi) szinten valósulnak meg: az egyes személyek jövedelmükkel a pénztárcájukban veszik meg az autót; a jelenség megfigyelési egységei a személy és az autó. Mégis, ettől a háttérismerettől egy faktoranalízises vizsgálat eredményeinek értékelésekor el kell tekinteni, mivel az absztrakció részeként adatainkat területileg csoportosítottként kezeljük.

El kell fogadni, hogy a faktoranalízis a relációkat közvetlenül egyetlen területi szinten tudja értelmezni, mégpedig azon, amelyiken az alapadataink vannak. Ezt a vizsgálatok legtöbbször figyelmen kívül hagyják. Beluszky és Sikos T. például azt írják, hogy ,a vizsgálatban használt 27 mutató (...) elegendőnek bizonyult a településformáló folyamatok megragadására" (Beluszky-Sikos T. 2007, 126), illetve hogy ezen mutatók által megragadott tényezők differenciálják a faluállományt. A települési adatok közötti kapcsolatok keresésével viszont nem lehet megragadni azokat a hatásokat, amelyeket például az országos település-, gazdaság- vagy társadalompolitika gyakorol a települések életére (általában, de nem mindig, a település lakosain keresztül). A koncepcionalizálási fázis tehát sokkal összetettebb, mint aminek látszik: ésszerú kompromisszumot kell hozni arról, hogy a valóságot milyen mértékben szabad egy adott területi szintre redukálni, hogy az még ne minősüljön túlságosan nagy mértékủ absztrakciónak. Hasonló megfontolásokat érdemes tenni az időbeli érvényesség kapcsán is, mert a módszer a változók egymásra hatását csak egy időkeresztmetszetben tudja mérni, amely legtöbbször - ha az alapadatok egy időpontból származnak - az egyidejüségre redukálódik. 


\section{Összefoglalás}

A faktoranalízis az utóbbi évtizedekben a hazai területi elemzések eszköztárának részévé vált, köszönhetöen annak is, hogy látszólag sikerrel oldja meg a vizsgálandó változók számának csökkentése mellett az összetett fogalmak mérésének problémáját is. Ugyanakkor a módszer mögött álló gondolatokról - az angolszász gazdaságföldrajzhoz hasonló módon (Barnes et al. 2007) - kevés vita zajlik. Egyetértünk Werlen azon, a faktorökológiai vizsgálatokról szóló, de valamennyi „területi szempontú" faktoranalízisre kiterjeszthető megállapításával, mely szerint előfordul, hogy a lényeges elméleti kérdéseket a kutatások eljárástechnikai fejtegetésekkel váltják fel, kevesen kérdezik meg, hogy mire is használható ténylegesen a módszer (Werlen 2008). Ahhoz, hogy a módszerekről valóban termékeny vitákat folytathassunk, nem elég nézöpontot (point of view) váltani, hanem szemléletmódot (way of seeing) is szükséges (Gregory 1994). A kizárólag az inputokra és outputokra figyelö feketedoboz-jelenséget szükséges felszámolni (Latour 1999), amire a kvantitatív és a kritikai nézőpont közeledését indítványozó tanulmányok (Barnes 2009; KwanSchwanen 2009) lehetőséget látnak.

Az eddigi hazai viták inkább a faktoranalízist, mint módszert elemezték különböző nézőpontból. Egyáltalán nem gondoljuk, hogy ezek hiábavaló eszmefuttatások, és azt sem, hogy az eljárás bizonyos kérdések vizsgálatára ne lenne alkalmas, ebben az írásban is feltett problémákon elgondolkozva és azokra válaszokat keresve. A tanulmányban annak a kérdésnek a mentén indultunk el, hogy valóban tekinthetünk-e a faktoranalízisre úgy, mint amely megoldja az összetett jelenségek mérésének problémáját. Ezt kizárólag olyan szemléletmóddal lehetett eredményesen megtenni, amellyel a megoldás univerzalitását megkérdőjeleztük.

\section{Jegyzet}

1 Ezúton köszönöm a tanulmány elöző, 2009. szeptember 25-én az ELTE Regionális Tudományi Tanszék Regionális Tudományi Esték rendezvénysorozatának keretében elỏadott változatát véleményező kollégák hasznos észrevételeit.

\section{Irodalom}

Adler J.-Barta J.-Benyó B.-Bíró P. (2001) A gazdasági fejlettség terïleti különbségei és ezek okai. Terilleti Statisztika. 6. 517-533. o.

Aitken, S.-Valentine, G. (2006) Ways of knowing and ways of doing geographical research. - Aitken, S.Valentine, G. (eds.) Approaches to human geography. Sage - Thousand Oaks, London - New Delhi. 1-12. o.

Barnes, T.J. (2001) Lives lived and lives told: biographies of geography's quantitative revolution. Environment and Planning D: Society and Space. 4. 409-429. o.

Barnes, T.J. (2004) A paper related to everything but more related to local things. - Annals of the Association of American Geographers. 2. 278-283. o.

Barnes, T.J. (2009) "Not only... but also": Quantitative and critical geography. - The Professional Geographer. 3. 292-300. o. 
Barnes, T.-Peck, J.-Sheppard, E.-Tickell, A. (2007) Methods matter: Transformations in economic geography. - Tickell, A.-Sheppard, E.-Peck, J.-Bames, T. (eds.) Politics and practice in economic geography. Sage - Thousand Oaks, London - New Delhi, Singapore. 1-24. o.

Belina, B. (2008) Geographische Ideologieproduktion - Kritik der Geographie als Geographie. - ACME: An International E-Journal for Critical Geographies. 3. 510-537. o.

Beluszky P.-Sikos T. T. (2007) Valtozó falvaink (Magyarország falutípusai az ezredfordulón). Magyarország az ezredfordulón. MTA Társadalomkutató Központ, Budapest.

Bíró P.-Molnár L. (2004) A kistérségi szintủ relatív fejlettség meghatározása. - Teruileti Statisztika. 6. 564-585. o.

Bottlik Zs. (2008) A regionális és etnikai különbségek összefüggései Bulgáriában az ezredfordulón. Teriuleti Statisztika. 3. 334-343. o.

Boudon, R. (2006) A dimenzióelemzés megoldatlan problémái. - Bertalan L. (szerk.) A kvantitatív társadalomkutatás modelljei. Klasszikus módszertani írások. Helikon Kiadó, h. n. 91-140. o.

Bourdieu, P. (2002) A gyakorlati észjarás: A társadalmi cselekvés elméletéröl. Napvilág Kiadó, Budapest.

Czirfusz M. (2007) Regionális gazdaságszerkezeti egyenlötlenségek. Diplomamunka. Eötvös Loránd Tudományegyetem Regionális Földrajzi Tanszék, Budapest.

Dusek T. (2004) A terïleti elemzések alapjai. Regionális Tudományi Tanulmányok. 10. ELTE Regionális Földrajzi Tanszék, MTA - ELTE Regionális Tudományi Kutatócsoport, Budapest.

Enyedi Gy. (2005) Milyen régió kell nekünk? Hozzászólás a Tóth József-interjúhoz. - Területi Statisztika. 4. 307-308.

Faluvégi A. (2005) A társadalmi-gazdasági jellemzók terileti alakulása az átmenet idỏszakában és az új évezred küszöbén. - Fazekas K.-Faluvégi A.-Nemes Nagy J.-Németh N. A hely és a fej-Munkapiac és regionalitás Magyarországon. KTI Könyvek. 6. MTA Közgazdaságtudományi Intézet, Budapest. 9-46. o.

Fassman[n], H. (1991) Faktorökológia - kutatási koncepció zsákutcában? - Tér és Társadalom. 1. 73-87. o.

Feyerabend, P. (1998) A tudomány módszerének misztifikálása ellen. - Magyar Lettre Internationale. 31. 64-67. 0 .

Foucault, M. (2001) A tudás archeológiaja. Atlantisz Kiadó, Budapest.

Foucault, M. (2007) A por és a felhö. - Benda Gy.-Szekeres A. (szerk.) Az Annales. A gazdaság-, társadalom- és müvelödéstörténet francia változata. Atelier füzetek. 9. L'Harmattan-Atelier, Budapest. 437-462. o.

Füller, H.-Michel, B. (2008) Zur poststrukturalistischen Kritik des Scale-Konzepts. Für eine (topologische) Machtanalyse. - Wissen, M. (Hrsg.) Politics of scale: Räume der Globalisierung und Perspektiven emanzipatorischer Politik. Westfälisches Dampfboot, Münster. 144-168. o.

Gregory, D. (1994) Geographical imaginations. Blackwell, Cambridge.

Johnston, R.J.-Sidaway, J.D. (2004) Geography \& geographers: Anglo-american human geography since 1945. Arnold, London.

Kitchin, R. (2006) Positivistic geographies and spatial science. - Aitken, S.-Valentine, G. (eds.) Approaches to human geography. Sage - Thousand Oaks, London - New Delhi. 20-29. o.

Kwan, M-P.-Schwanen, T. (2009) Guest editorial. Critical quantitative geographies. - Environment and Planning A. 2. 261-264. o.

Latour, B. (1999) Pandora's hope. Essays on the reality of science studies. Harvard University Press, Cambridge, Mass.

Massey, D. (1985) New directions in space. - Gregory, D.-Urry, J. (eds.) Social relations and spatial structures. Macmillan, London. 9-19. o.

Massey, D.B. (1995) Spatial divisions of labour: Social structures and the geography of production. Macmillan, London.

Nemes Nagy J. (1988) A hazai területi kutatások mennyiségi elemzési kultúrája. - Tér és Társadalom. 4. $68-81.0$.

Nemes Nagy J. (szerk.) (2005) Regionális elemzési módszerek. Regionális Tudományi Tanulmányok. 11. ELTE Regionális Földrajzi Tanszék, MTA-ELTE Regionális Tudományi Kutatócsoport, Budapest.

Nemes Nagy J. (2009) Terek, helyek, régiok. A regionális tudomány alapjai. Modem regionális tudományi szakkönyvtár. Akadémiai Kiadó, Budapest.

Probáld F. (1995) A regionális földrajz helye a geográfiában (Háttérvázlat). - Nemes Nagy J. (szerk.) Földrajz, regionális tudomány (Tudományelméleti tanulmányok). Regionális Tudományi Tanulmányok. 2. ELTE Regionális Földrajzi Tanszék, Budapest. 35-62. o.

Sayer, A. (1985) The difference that space makes. - Gregory, D.-Urry, J. (eds.) Social relations and spatial structures. Macmillan, London. 49-66. o. 
Székelyi M.-Barna I. (2002) Túlélỏkészlet az, SPSS-hez. Többváltozós elemzési technikákról társadalomkutatók számára. Typotex, Budapest.

Tóth J. (2004) Kell-e nekünk régió? - Hitseker M.-Szilágyi Zs. (szerk.) Mindentudás egyeteme. 3. Kossuth Kiadó, Budapest. 193-212. o.

Werlen, B. (2008) Sozialgeographie. Eine Einfiihrung. Haupt Verlag, Bern, Stuttgart, Wien.

\section{FACTOR ANALYSIS: A PSEUDO-SOLUTION}

\section{MÁRTON CZIRFUSZ}

Factor analysis is often regarded as being the general solution to measure and quantify multifaceted terms, like development. The article questions this standpoint and argues for more theoretical debate about methods and methodology with examining the factor analysis more thoroughly. The first half of the paper deals with the problems of abstraction in using the method (dimensions, variables, factors and its associations) and dissects the practices of mapping, writing about the world and creating order. In the second half contradictions between a spatial fetishist and a spatial nihilist argumentation throughout the usage of the method, as well as special issues of geographical scales are shown. The article uses theoreticalphilosophical literature to open up the black box of the factor analysis and brings questionable examples from the Hungarian literature of the past decades. 